\title{
KANDUNGAN KALIUM DAN RASIO C/N PUPUK ORGANIK CAIR (POC) BERBAHAN DAUN-DAUNAN DAN URINE KAMBING DENGAN PENAMBAHAN BIOAKTIVATOR RAGI TAPE (Saccharomyces cerevisiae) \\ (Postassium content and $\mathrm{C} / \mathrm{N}$ ratio of Liquid Organic Fertilizer Made from The Leaves and Goat Urine with the addition of Tape Yeast Bioactivator (Saccharomyces cerevisiae))
}

\author{
T. I. Rahmawati ${ }^{11^{*}}$, A. Asriany ${ }^{2)}$, S. Hasan ${ }^{2)}$ \\ ${ }^{1)}$ Mahasiswa Program Strata Satu Fakultas Peternakan, Universitas Hasanuddin. \\ ${ }^{2)}$ Fakultas Peternakan, Universitas Hasanuddin. \\ *Email: tiwiika7@gmail.com
}

\begin{abstract}
Environmental problems in various places, including waste issue in the campus of the Faculty of Animal Husbandry Makassar. Pollution caused by waste in the campus environment of Hasanuddin University Makassar farm if left unchecked will cause disease, foul odors and disturb the aesthetic environment. One of which is by utilizing the leaf litter as liquid organic fertilizer. This study aims to determine the content of potassium and $\mathrm{C} / \mathrm{N}$ ratio of liquid organic fertilizer made from organic waste and goat urine with the addition of ragi yeast bioactivators. This study consisted of four treatments i.e T0 (95\% organic wate $+5 \%$ tape yeast), T1 $(70 \%$ organic waste $+25 \%$ goat urine $+5 \%$ ragi yeast $)$, T2 (50\% organic waste $+45 \%$ goat urine $+5 \%$ tape yeast), T3 (25\% orgnic waste $+70 \%$ goat urine $+5 \%$ ragi yeast). This study was arranged according to Completely Randomized Design (CRD) consisting of 4 treatments and 3 replications, analysis of variance showed liquid organic fertilizer made from organic waste and urine of goat with the addition of tape yeast bioactivator had no significant effect $(\mathrm{P}>0.05)$ on potassium content of potassium according to treatments are $(\mathrm{T} 0=0.25 \pm 0.06) ;(\mathrm{T} 1=0.19 \pm 0.09) ;(\mathrm{T} 2=$ $0.33 \pm 0.08) ;(\mathrm{T} 3=0.31 \pm 0.05)$ while for tne $\mathrm{C} / \mathrm{N}$ ratio obtained $(\mathrm{T} 0=7.7 \pm 5.81)$; $(\mathrm{T} 1=8.1 \pm 2.85) ;(\mathrm{T} 2=7.8 \pm 0.25) ;(\mathrm{T} 3=7.3 \pm 4.52)$. The result of the study it can be concluded that the level of percentage or raw material for making liquid organic fertilizer does not have a significant effect on potassium content and $\mathrm{C} / \mathrm{N}$ ratiovof liquid organic fertilizer.
\end{abstract}

Keywords: Bioactivator, Potassium, Liquid Organic Fertilizer,C/N Ratio, and Goat Urine 
T. I Rahmawati, A. Asriany, S. Hasan/Buletin Nutrisi dan Makanan Ternak 14(2) : 50-60

\begin{abstract}
ABSTRAK
Permasalahan lingkungan di berbagai tempat, termasuk permasalahan sampah di lingkup kampus Fakultas Peternakan Universitas Hasanuddin, Makassar. Pencemaran akibat sampah di lingkungan kampus Fakultas Peternakan Universitas Hasanuddin Makassar apabila dibiarkan akan menimbulkan penyakit, bau busuk serta mengganggu estetika lingkungan. Salah satunya dengan memanfaatkan sampah daundaunan sebagai pupuk organik cair. Penelitian ini bertujuan untuk mengetahui kandungan kalium dan $\mathrm{C} / \mathrm{N}$ rasio pupuk organik cair berbahan daun-daun dan urine kambing dengan penambahan bioaktivator ragi tape (Saccharomyces cerevisiae). Penelitian terdiri dari empat perlakuan T0 (95\% daun-daunan $+5 \%$ ragi tape ), T1 (70\% daun-daunan $+25 \%$ urine kambing $+5 \%$ ragi tape), T2 (50\% daun-daunan + $45 \%$ urine kambing $+5 \%$ ragi tape), T3 (25\% daun-daunan $+70 \%$ urine kambing + $5 \%$ ragi tape). Rancangan yang digunakan adalah Rancangan Acak Lengkap (RAL) yang terdiri 4 perlakuan dan 3 ulangan. Analisis statistik memperlihatkan bahwa pembuatan pupuk organik cair berbahan daun-daunan dan urine kambing dengan penambahan bioaktivator ragi tape (Saccharomyces cerevisiae) tidak berpengaruh nyata $(\mathrm{P}>0,05)$ terhadap kandungan kalium dan rasio $\mathrm{C} / \mathrm{N}$. Berdasarkan hasil penelitian diperoleh kalium $(\mathrm{T} 0=0.25 \pm 0.06) ;(\mathrm{T} 1=0.19 \pm 0.09) ;(\mathrm{T} 2=0.33 \pm 0.08)$; $(\mathrm{T} 3=0.31 \pm 0.05)$ sedangkan untuk rasio $\mathrm{C} / \mathrm{N}$ diperoleh $(\mathrm{T} 0=7.7 \pm 5.81) ; \quad(\mathrm{T} 1=$ $8.1 \pm 2.85) ;(\mathrm{T} 2=7.8 \pm 0.25) ;(\mathrm{T} 3=7.3 \pm 4.52)$. Berdasarkan hasil penelitian dapat disimpulkan bahwa level persentase bahan baku pembuatan pupuk organik cair tidak memberikan pengaruh yang signifikan terhadap kandungan kalium dan rasio $\mathrm{C} / \mathrm{N}$ pupuk organik cair.
\end{abstract}

Kata kunci: Bioaktivator, Kalium, Pupuk Organik Cair, Rasio C/N dan Urine Kambing

\title{
PENDAHULUAN
}

Permasalahan lingkungan di berbagai tempat, termasuk permasalahan sampah daun-daunan di lingkup kampus Fakultas Peternakan Universitas Hasanuddin, Makassar. Permasalahan itu menyangkut pencemaran, baik pencemaran tanah, air, dan udara. Pencemaran tersebut diakibatkan oleh aktivitas manusia maupun alam. Pencemaran tanah misalnya, banyaknya sampah daun - daunan yang tertimbun di 
T. I Rahmawati, A. Asriany, S. Hasan/Buletin Nutrisi dan Makanan Ternak 14(2) : 50-60

tempat sampah serta sampah daun - daunan yang gugur, apabila tidak ditangani dengan baik akan menurunkan tingkat kesehatan masyarakat.

Sampah dikelompokkan menjadi dua yaitu sampah organik dan sampah anorganik. Sampah organik contohnya adalah sampah dedaunan, limbah ternak dan lain-lain. Pencemaran akibat sampah daun-daunandilingkungan kampus Fakultas Peternakan Universitas Hasanuddin Makassar, bila dibiarkan akan mengganggu estetika lingkungan. Sampah daun-dauan ini mempunyai potensi yang cukup besar dan memiliki nilai ekonomis yang tinggi, maka dari itu perlu dilakukan upaya untuk mengurangi pencemaran akibat sampah daun-daunansalah satunya dengan memanfaatkan sampah daun-daunan sebagai pupuk organik cair.

Pupuk organik cair merupakan pupuk yang bahan dasarnya berasal dari hewan atau tumbuh-tumbuhan yang telah mengalami proses fermentasi dan produk akhirnya berbentuk cair. Urine kambing merupakan limbah ternak yang potensial untuk digunakan sebagai pupuk organik cair. Urine kambing memiliki kandungan kalium tinggi dibandingkan dengan urine ternak lain. Dalam proses fermentasi pupuk cair, peranan mikroba sangat menentukan produk yang dihasilkan. Salah satu mikroba yang dapat berfungsi sebagai aktivator dalam proses fermentasi pupuk organik cair adalah ragi Saccharomyces cerevisiae. Pupuk organik cair mampu menyediakan unsur hara makro seperti nitrogen $(\mathrm{N})$, fosfor $(\mathrm{P})$, dan kalium $(\mathrm{K})$ untuk tanah maupun tanaman. Pupuk organik cair lebih mudah terserap oleh tanaman, karena senyawa kompleks yang terdapat dalam pupuk cair sudah terurai dan dalam bentuk cair sehingga mudah diserap oleh tanaman, baik melalui akar ataupun daun.

Salah satu aspek terpenting dalam keseimbangan unsur hara adalah rasio organik karbon dengan nitrogen (Rasio $\mathrm{C} / \mathrm{N}$ ). Rasio $\mathrm{C} / \mathrm{N}$ bahan organik adalah perbandingan antara banyaknya unsur karbon (C) terhadap banyaknya kandungan unsur nitrogen (N) yang ada pada suatu bahan organik. Mikroorganisme membutuhkan karbon dan nitrogen untuk aktifitas hidupnya (Djuarnani, 2005). 
T. I Rahmawati, A. Asriany, S. Hasan/Buletin Nutrisi dan Makanan Ternak 14(2) : 50-60

Tujuan dilakukannya penelitian ini yaitu untuk mengetahui kandungan kalium dan rasio $\mathrm{C} / \mathrm{N}$ pupuk organik cair berbahan daun - daunan dan urine kambing dengan penambahan bioaktivator ragi tape Saccharomyces cerevisiae.

\section{METODE PENELITIAN}

\section{Waktu dan Tempat Penelitian}

Penelitian ini dilaksanakan pada bulan November 2019 dengan dua tahap yaitu tahap pertama dilakukan pembuatan pupuk organik cair dilaksanakan di Laboratorium Tanaman Pakan dan Pastura, Fakultas Peternakan, Universitas Hasanuddin, Makassar. Tahap kedua yaitu analisa Kalium dan Rasio C/N pupuk organik cair dilaksankan di Laboratorium Kimia dan Kesuburan Tanah, Fakultas Pertanian, Universitas Hasanuddin, Makassar.

\section{Materi Penelitian}

Alat yang akan digunakan pada penelitian ini antara lain ember ukuran5 liter, gelas ukur, saringan, alat tulis, kain penutup, parang, pengaduk dan peralatan analisis Kalium dan Rasio C/N.

Bahan yang akan digunakan pada penelitian ini antara lain sampah daundaunansebanyak 2 karung, urine kambing sebanyak 10 liter yang diambil di kandang kambing Fakultas Peternakan Universitas Hasanuddin, air dan ragi tape $5 \%$ yang diperoleh dipasar.

\section{Metode Pelaksanaan a.Rancangan penelitian}

Rancangan percobaan yang akan digunakan dalam penelitian ini adalah Rancangan Acak Lengkap (RAL) (Gasperzs, 1994) dengan 4 perlakuan dan 3 ulangan sebagai berikut :

T0 : 95\% sampah organik $+5 \%$ ragi tape

$\mathrm{T} 1: 70 \%$ sampah organik $+25 \%$ urine mbing $+5 \%$ ragi tape

T2 : 50\% sampah organik $+45 \%$ urine kambing $+5 \%$ ragi tape

$\mathrm{T} 3: 25 \%$ sampah organik $+70 \%$ urine kambing $+5 \%$ ragi tape 
T. I Rahmawati, A. Asriany, S. Hasan/Buletin Nutrisi dan Makanan Ternak 14(2) : 50-60

Total unit experimen adalah sebanyak 12 unit percobaan.

\section{b. Prosedur penelitian}

Prosedur Pembuatan Pupuk Organik Cair

Pada pembuatan pupuk organik cair ada beberapa tahap yang dilakukan sebagai berikut :

1. Alat dan bahan yang akan digunakan disiapkan terlebih dahulu.

2. Sampah yang telah disiapkan, dipisahkan antara sampah organik dan sampah anorganik.

3. Setelah terpisah antara sampah organik dan anorganik, sampah organik (daundaunan) dicacah atau haluskan, lalu tumbuk atau haluskan ragi tape, kemudian timbang masing-masing bahan sesuai dengan perlakuan T0; T1; T2 dan T3.

4. Masukkan sampah daun-daunandan ragi tape yang telah dihaluskan sebanyak $5 \%$ yang telah dihaluskan/dicacah kedalam ember ukuran 5 liter. Kemudian masukkan urine kambing pada setiap perlakuan.

5. Setelah itu aduk hingga homogen atau tercampur rata.

6. Tutup rapat ember dan disimpan ditempat yang teduh atau terlindung dari paparan sinar matahari, disimpan selama kurang lebih 14 hari.

7. Proses fermentasi dinyatakan berhasil apabila dari dalam ember tidak keluar bau urine kambing yang menyengat.

8. Setelah fermentasi selesai pupuk cair disaring, pupuk cair diaplikasikan.

Parameter yang diamati pada penelitian ini adalah kandungan kalium dan rasio $\mathrm{C} / \mathrm{N}$ pupuk organik cair.

\section{c. Analisis Data}

Data yang diperoleh secara statistik dengan menggunakan Rancangan Acak Lengkap (RAL) terdiri 4 perlakuan dan 3 kali ulangan (Gasperzs, 1994).

Model matematika adalah sebagai berikut:

$$
Y i j=\mu+T i+\epsilon i j
$$


T. I Rahmawati, A. Asriany, S. Hasan/Buletin Nutrisi dan Makanan Ternak 14(2) : 50-60

Keterangan:

Yij = Nilai pengamatan dari perlakuan ke-i $(1,2,3,4,5)$ dan ulangan ke-j $(1,2,3,4)$

$\mu \quad=$ Rata-rata pengamatan

$\mathrm{Ti}=$ Pengaruh perlakuan ke-i $(1,2,3,4$, dan 5$)$

$€ \mathrm{ij}=$ Galat percobaan akibat perlakuan ke-i dan ulangan ke-j $(1,2,3,4)$

Pengaruh perlakuan terhadap paramater yang diukur, dianalisis data dengan menggunakan ragam (ANOVA). Apabila perlakuan berbeda nyata maka dilanjutkan dengan uji Duncan untuk mengetahui perbedaan pengaruh antar setiap perlakuan (Gomez dan Gomez, 2010).

\section{HASIL DAN PEMBAHASAN}

Hasil perhitungan rata - rata kandungan kalium dan rasio $\mathrm{C} / \mathrm{N}$ pada setiap perlakuan pupuk organik cair berbahan daun-daunan dan urine kambing dengan penambahan bioaktivator ragi tape (Saccharomyces cerevisiae) dapat dilihat pada Tabel 3.

Tabel3. Rata-rata kandungankalium dan rasio C/Npupukorganikcair

\begin{tabular}{lcccc}
\hline & \multicolumn{4}{c}{ Perlakuan } \\
\cline { 2 - 5 } Parameter & T0 & T1 & T2 & T3 \\
\hline Kalium $(\%)$ & $0.25 \pm 0.06$ & $0.19 \pm 0.09$ & $0.33 \pm 0.08$ & $0.31 \pm 0.05$ \\
Rasio C/N & $7.7 \pm 5.81$ & $8.1 \pm 2.85$ & $7.8 \pm 0.25$ & $7.3 \pm 4.52$ \\
\hline Analisis Laboratorium Kimia dan Kesuburan & Tanah, Fakultas & Pertanian, Universitas Hasanuddin \\
(2019).
\end{tabular}

\section{Pengaruh Pembuatan Pupuk Organik Cair (POC) Berbahan Daun-daunan dan Urine Kambing dengan Penambahan Bioaktivator Ragi Tape (Saccharomyces cerevisiae) terhadap Kandungan Kalium}

Berdasarkan hasil analisis sidik ragam (Lampiran 1) menunjukkan bahwa perlakuan pembuatan pupuk organik cair berbahan daun-daunan dan urine kambing dengan penambahan bioaktivator ragi tape (Saccharomyces cerevisiae) tidak berpengaruh nyata $(\mathrm{P}>0.05)$ terhadap kandungan kalium pupuk organik cair. Ratarata kandungan kalium pupuk organik cair tertinggi terdapat pada perlakuan T2 yaitu 
T. I Rahmawati, A. Asriany, S. Hasan/Buletin Nutrisi dan Makanan Ternak 14(2) : 50-60

$0.33 \pm 0.08$. Tingginya kandungan kalium ini disebabkan karena unsur Kalium (K) merupakan katalisator bagi mikroba atau mikroorganisme untuk mempercepat proses fermentasi. Selain itu penambahan bioaktivator dalam pembuatan pupuk cair juga mempengaruhi tingginya kalium dalam pupuk. Artinya, jika proses fermentasi yang berjalan dengan cepat dan diiringi dengan bahan baku pendukung yang tepat maka kandungan kalium juga akan meningkat. Hal ini sesuai dengan pendapat Hidayati et al. (2011) yang menyatakan bahwa unsur kalium dalam senyawa kalium dioksida $\left(\mathrm{K}_{2} \mathrm{O}\right)$ yang digunakan oleh mikroorganime dalam bahan substrat sebagai katalisator, akan mempengaruhi keberadaan bakteri dan aktivitasnya dalam proses fermentasi. Kalium diikat dan disimpan dalam sel oleh bakteri dan jamur, jika di degradasi kembali maka kalium akan tersedia kembali (Mirwan dan Rosariawari, 2012).

Kandungan kalium pupuk organik cair terendah terdapat pada perlakuan T1 yaitu $0.19 \pm 0.09$. Rendahnya kandungan kalium ini disebabkan oleh terjadinya endapan pada pupuk organik cair sehingga unsur K (kalium) tidak terdeteksi secara sempurna selain itu konsentrasi pada bahan dalam pembuatan pupuk organik cair membuat unsur kalium menjadi rendah. Dalam penelitian ini terdapat perbedaan kandungan nitrogen dan kalium pada setiap perlakuan. Hal ini juga disebabkan oleh perbedaan kecepatan mikroorganisme dalam mengurai bahan organik saat fermentasi (Mulyadi, 2013).

Perbedaan kandungan kalium pada setiap perlakuan disebabkan oleh perbedaan konsentrasi bahan pembuatan pupuk cair. Kandungan kalium dalam pupuk cair ini tergolong rendah dan belum memenuhi standar mutupupukorganikcair. Menurut Peraturan Menteri Pertanian No 70 Tahun 2011, standar mutu kandungan nitrogen dan kalium masing-masing 3-6\%. Sedangkan pupuk organik cair dari hasil pnelitian ini mengandung kalium $<1 \%$. 
T. I Rahmawati, A. Asriany, S. Hasan/Buletin Nutrisi dan Makanan Ternak 14(2) : 50-60

\section{Pengaruh Pembuatan Pupuk Organik Cair (POC) Berbahan Daun-daunan dan Urine Kambing dengan Penambahan Bioaktivator Ragi Tape (Saccharomyces cerevisiae) terhadap Kandungan Rasio $\mathrm{C} / \mathrm{N}$}

Berdasarkan hasil analisis sidik ragam (Lampiran 3), menunjukkan bahwa antara kombinasi persentase pembuatan pupuk organik cair berbahan daun-daunan dan urine kambing dengan penambahan bioaktivator ragi tape tidak memberikan pengaruh nyata $(\mathrm{P}>0.05)$ terhadap kandungan rasio $\mathrm{C} / \mathrm{N}$ pupuk organik cair. Ratarata kandungan rasio $\mathrm{C} / \mathrm{N}$ pupuk organik cair, hasil tertinggi pada perlakuan $\mathrm{T} 1$ yaitu 8.1 \pm 2.85 . Rasio $\mathrm{C} / \mathrm{N}$ yang terkandung dalam pupuk cair menunjukkan tingkat kematangan dari pupuk cair tersebut, dari hasil penelitian ini dikatakan bahwa pupuk organik cair belum matang karena pupuk belum terurai secara sempurna. Hal ini sesuai dengan literatur yang menyatakan, jika rasio $\mathrm{C} / \mathrm{N}$ terlalu tinggi (banyak unsur C dan sedikit unsur N), metabolisme menjadi tidak memadai yang berarti bahwa ada karbon dalam substrat tidak sepenuhnya dikonversi, sehingga tidak akan tercapai hasil metana yang maksimum. Dalam kasus sebaliknya, surplus nitrogen dapat menyebabkan pembentukan jumlah berlebihan amonia $\left(\mathrm{NH}_{3}\right)$, yang bahkan dalam konsentrasi rendah akan menghambat pertumbuhan bakteri (Ridlo, 2017).

Kandungan rasio $\mathrm{C} / \mathrm{N}$ pupuk organik cair terendah terdapat pada perlakuan $\mathrm{T} 3$ yaitu 7.3 \pm 4.52 . Rendahnya kandungan rasio $\mathrm{C} / \mathrm{N}$ pupuk karena adanya penurunan pada kadar C dan meningkatnya kadar N seiring berjalannya waktu. Selain itu rendahnya kandungan rasio $\mathrm{C} / \mathrm{N}$ pupuk organik cair juga diakibatkan oleh kandungan dan aktivitas mikroorganisme. Semakin lama proses fermentasi yang dilakukan maka rasio $\mathrm{C} / \mathrm{N}$ semakin kecil. Hal ini disebabkan kadar $\mathrm{C}$ dalam bahan pembuatan pupuk cair sudah banyak berkurang karena digunakan oleh mikroorganisme sebagai sumber makanan atau energi, sedangkan kandungan nitrogen mengalami peningkatan karena proses dekomposisi bahan pupuk cair oleh mikroorganisme yang menghasilkan amonia dan nitrogen sehingga rasio $\mathrm{C} / \mathrm{N}$ menurun (Surtinah, 2013).

Rasio $\mathrm{C} / \mathrm{N}$ bahan organik merupakan faktor yang paling penting dalam proses pembuatan pupuk cair. Hal tersebut disebabkan mikroorganisme membutuhkan 
T. I Rahmawati, A. Asriany, S. Hasan/Buletin Nutrisi dan Makanan Ternak 14(2) : 50-60

karbon untuk menyediakan energi (Gunawan dan Surdiyanto, 2001) dan nitrogen yang berperan dalam memelihara dan membangun sel tubuhnya (Triatmojo, 2001). Rasio $\mathrm{C} / \mathrm{N}$ yang tinggi akan mengakibatkan proses fermentasi berjalan lambat karena kandungan nitrogen yang rendah, sebaliknya jika rasio $\mathrm{C} / \mathrm{N}$ terlalu rendah akan menyebabkan terbentuknya amonia, sehingga nitrogen akan hilang ke udara (Gunawan dan Surdiyanto, 2001).

Rasio C/N dapat digunakakan sebagai indikator proses fermentasi, jika jumlah perbandingan antara karbon dan nitrogen masih berkisar antara 20\% sampai 30\% maka hal tersebut mengidentifikasikan bahwa pupuk yang difermentasi sudah bisa digunakan. Perbedaan kandungan $\mathrm{C}$ dan $\mathrm{N}$ tersebut akan menentukan kelangsungan proses fermentasi pupuk cair yang pada akhirnya mempengaruhi kualitas pupuk cair yang dihasilkan (Pancapalaga, 2011).

\section{KESIMPULAN}

Berdasarkan hasil penelitian dapat disimpulkan bahwa level persentase bahan baku pembuatan pupuk organik cair tidak memberikan pengaruh yang signifikan terhadap kandungan kalium dan rasio $\mathrm{C} / \mathrm{N}$ pupuk organik cair.

\section{DAFTAR PUSTAKA}

Djuarnani. 2005. Cara Cepat Membuat Kompos. Agromedia Pustaka. Jakarta.

Eviati dan Sualeman. 2009. Analisis kimia tanah, air, dan pupuk. Balai Penelitian Tanah. Bogor.

Gasperzs, V. 1994. Metode Rancangan Percobaan. Armico. Bandung.

Gomez, K.A., dan A.A. Gomez. 2010. Prosedur Statistika untuk Penelitian Pertanian (Terjemahkan) Endang Sjamsuddin dan J.S. Baharsjah. Edisi Kedua. UI Press. Jakarta.

Gunawan, A. dan Y. Surdiyanto. 2001. Pembuatan kompos dengan bahan baku kotoran sapi. Jurnal Ilmu Pengetahuan dan Teknologi Peternakan. 24 (3):1217. 
T. I Rahmawati, A. Asriany, S. Hasan/Buletin Nutrisi dan Makanan Ternak 14(2) : 50-60

Hidayati, Y.A., T.. Benito A. Kurniawan, E. T. Marlina, dan E. Harlia. 2011. Kualitas Pupuk Cair Hasil Pengolahan Feses Sapi Potong Menggunakan Saccharomyces cereviceae. Jurnal Ilmu Ternak 11(2): 104-107.

Kurniawan, E., Z. Ginting, dan P. Nurjannah,. 2017. Pemanfaatan urine kambing pada pembuatan pupuk organik cair terhadap kualitas unsur hara makro (NPK). Seminar Nasional Sains dan Teknologi. Fakultas Teknik Universitas Muhammadiyah. Jakarta.

Mirwan, M. dan F Rosariawari. 2012. Optimasi pematangan kompos dengan penambahan campuran lindi dan bioaktivator stardec. Jurnal Ilmiah Teknik Lingkungan 4(2): 150-154.

Mulyadi, Y. 2013. Studi Penambahan Air Kelapa pada Pembuatan Pupuk Cair Limbah Ikan terhadap Kandungan Hara Makro C, N, P, dan K. Skripsi. Fakultas Pertanian dan Peternakan. UNDIP. Semarang.

Mulyono. 2016. Membuat MOL dan Kompos dari Sampah Rumah Tangga. AgroMedia Pustaka. Jakarta.

Pancapalaga, W. 2011. Pengaruh Rasio Penggunaan Limbah Ternak dan Hijauan terhadap Kualitas Pupuk Cair, Jurnal Gamma 7 (1): 61-68.

Rahmah, A., Izzati, M. \&Parman, S. 2014. Pengaruh Pupuk Organik Cair Berbahan Dasar Limbah Sawi Puth (Brassica chinensis L.) terhadap Pertumbuhan Tanaman Jagung Manis (Zea mays L. var. Saccharata). Jurnal Anatomi dan Fisiologi, 112.

Rahmawati, A. 2010. Pemanfaatan limbah kulit ubi kayu (Manihot utilissima pohl.) dan kulit nanas (Ananas comosus l.) pada produksi bioetanol menggunakan aspergillus niger. (Skripsi Jurusan Biologi). Universitas Sebelas Maret. Surakarta.

Ridlo, Rohmadi. 2017. Dasar-dasar fermentasi anaerobik. BPPT. PTSEIK.

Setiawan A, I. 2007. Memanfaatkan Kotoran Ternak. Penebar Swadaya. Jakarta.

Sundari, E., E. Sari. dan R Rinaldo.2012. Pembuatan Pupuk Organik Cair Menggunakan Bioaktivator Biosca dan EM4. Fakultas Teknologi Industri Universitas Bung Hatta. Palembang.

Surtinah. 2013. Pengujian kandungan unsur hara dalam kompos yang berasal dari serasah tanaman jagung manis (Zea mays saccharata). Jurnal Ilmiah Pertanian 11(1): 16-25. 
T. I Rahmawati, A. Asriany, S. Hasan/Buletin Nutrisi dan Makanan Ternak 14(2) : 50-60

Syakir, M. D. Allorerung, Sumanto dan J. Purani. 2009. Dekomposisi Limbah Jarak Pagar dan Pemanfaatannya untuk Pupuk Organik. Laporan Penelitian Insentif Riset. 2009. Pusat Penelitian dan Perkembangan Perkebunan. Bogor.

Triatmojo, S. 2001. Kualitas kompos yang diproduksi dari feses sapi perah dan sludge limbah penyamakan kulit. Buletin Peternakan. Jakarta.

Yuwono, T. 2006. Kecepatan Dekomposisi dan Kualitas Kompos Sampah Organik. Jurnal Inovasi Pertanian.4(2):116-123 